\title{
Textural Analysis of Spongy Indian Milk Dessert (Rasogolla) Fortified with Potato Powder
}

\section{Chaitali Chakraborty* and Kakali Bandyopadhyay}

\author{
Department of Food Technology, Guru Nanak Institute of Technology, 157/F, Nilgunj Road, \\ Panihati, Sodepur, Kolkata-700114, West Bengal, India \\ *Corresponding author
}

\begin{tabular}{|c|c|}
\hline & A B S T R A C T \\
\hline & \multirow{6}{*}{$\begin{array}{l}\text { Potato is probably the most popular food item in the Indian diet and India is one of the } \\
\text { largest producers of potato. Potato is a very rich source of starch. It also contains } \\
\text { phosphorus, calcium, iron and some Vitamins C and A. It is vastly consumed as a } \\
\text { vegetable and is also used in various forms such as starch, flour, alcohol and dextrin. } \\
\text { Besides being used as a daily food item in various vegetable preparations, potato today } \\
\text { increasingly finds use in the form of chips or wafers as snacks food. In the present study, } \\
\text { potato powder is produced from two varieties of potato like kufri chandramukhi and kufri } \\
\text { jyoti. These potato powders are utilized as a binding agent to produce fortified rasogolla } \\
\text { sample R1 (kufri jyoti fortified) and R2 (kufri chandramukhi fortified). Control sample (C) } \\
\text { of rasogolla is prepared using chhana (a heat and acid coagulated milk protein mass and an } \\
\text { Indian equivalent to cottage cheese) only and a market sample (M) is also taken into } \\
\text { consideration during comparative analysis of both sensory and texture. It has been found } \\
\text { that the highest overall acceptability of about } 8.7 \text { (based on 9-point hedonic scale) is } \\
\text { observed for sample R2 compared with others. Whereas considering the textural profile } \\
\text { like hardness, fracturability, springiness and cohesiveness the sample R2 provides } \\
\text { comparable result with other control and market sample. }\end{array}$} \\
\hline Keywords & \\
\hline $\begin{array}{l}\text { Potato powder, } \\
\text { Rasogolla, Texture } \\
\text { analysis, Sensory } \\
\text { analysis, Chhana }\end{array}$ & \\
\hline Article Info & \\
\hline $\begin{array}{l}\text { Accepted: } \\
\text { 20 March } 2017 \\
\text { Available Online: } \\
10 \text { April } 2017\end{array}$ & \\
\hline & \\
\hline
\end{tabular}

\section{Introduction}

Today potatoes have become an integral part of much of the world's cuisine and are the world's fourth-largest food crop, following rice, wheat, and maize. China is now the world's largest potato-producing country, and nearly third of the world's potatoes are harvested in China and India. Potatoes have high nutritive value and can be consumed in various forms and one of these is potato powder [International Year of the Potato 2008 - The potato (2009)]. Processing of potato into flour is the most satisfactory method of creating a product that is not only functionally adequate, but also remain for an extended period without damage. Potato flour can become a highly viable value added product due to its versatility in function as a thickener and color or flavor improver (Avula et al., 2006; Raj et al., 2008). Several products are prepared by incorporating potato flour with other flours and using the processes like baking, roasting, steaming, boiling and deep fat frying (Gahlawat and Sehgal, 1996).

It also imparts a distinctive, pleasing flavour and improves toasting qualities and can be 
used advantageously in crackers, pastries, yeast raised doughnuts, cake and cake mixes. Products such as gulab jamun, and paratha containing potato flour were more acceptable than those made with wheat flour alone (Kulakarni et al., 1996). Rekha et al., (2009) formulated soup mix using modified potato flour with reduced paste viscosities. Marwaha and Sandhu (1996) reported the use of potato flour as a combined thickener - flavoring agent in dehydrated soups, gravies, sauces and baby foods. Potato powder can also be used as a thickener in the preparation of kheer (Chakraborty et al., 2012) and soup (Saha et al., 2014).

Nath and Chatopadhyay (2008) developed ready to eat snack using high temperature short time air puffing, and Bastos-Cardoso et al., 2007 developed extruded pellets of whole potato flour by microwave heating. The suitability of potato varieties for a particular process depends upon their nutritional composition such as the dry matter content, sugars, protein and other nitrogenous compounds. Studies on storage and microbial safety of potato flour revealed that the flour can be kept safely in polyethylene pouches for six months at room temperature and refrigerated temperature without any spoilage (Mishra and Kulshrestha, 2002).

Potato flour ranks quite high in its supply of principal nutrients like protein, fiber and carbohydrates. Its protein content is superior to that of cassava and yam flour, and similar to that of rice. Potato flour has higher levels of fiber than refined wheat flour, maize meal, and rice. Its carbohydrate and energy contents are comparable to those of similar foods (Kulakarni et al., 1996).

Traditional dairy products such as Rasogolla are important, well balanced food, which contribute a number of nutrients in relation to consumer need for good nutrition and health.
Rasogollas' projected demand is 6000 tonnes in 2009 (Karunanithy et al., 2007). Rasogolla, one of the most popular and delicious sweet of India is prepared from chhana. Thus Rasogolla can be a most important food item for fortification of natural food sources. Bandyopadhyay et al., (2007) studied on the physical and sensory characteristics of low fat dairy dessert (Rasogolla) fortified with natural source of $\beta$ - carotene. Chavan et al., (2009) developed dietetic and diabetic Rosogolla using aspartame and sorbitol.

This study investigates rheological and sensory characteristics of Rasogolla, fortified with kufri jyoti and kufri chandramukhi potato powder and the results are compared with conventional Rasogolla.

\section{Materials and Methods}

\section{Raw material}

Potatoes of two different varieties, kufri jyoti and kufri chandramukhi were purchased from local market of Kolkata, West Bengal. Other materials used were cow milk, lactic acid, cardamom, KMS, sugar and salt.

\section{Preparation of potato powder}

Potatoes were washed thoroughly; peels were removed by using a peeler and sliced by using knife. The slices were blanched using $2 \%$ KMS solution for 30 minutes. The slurry was prepared using blanched slices and air dried at $76^{\circ} \mathrm{C}$ for 4-6 hours in a tray drier. The sample was grinded in powder form and passed through 120 mesh sieve. The through fraction was collected and packed for further use.

\section{Preparation of chhana}

The method outlined by De and Ray (1954) was followed with suitable modification given by Bhattacharya et al., 1971. The 
standardized cow milk was heated up to $75^{\circ}$ C. The freshly prepared coagulant (1\% citric acid solution) was heated to $75^{\circ} \mathrm{C}$ and then added slowly in a thin continuous stream with continuous gentle agitation till a clear whey separated out. Stirring was then stopped and the curd was allowed to remain in whey for about $5 \mathrm{~min}$. It was then drained through a hang with muslin cloth (10 min) and then used for preparation of Rasogolla.

\section{Preparation of potato powder based rasogolla}

Prepared Chhana was blended. 3\% Potato powder was mixed with Chhana and kneaded thoroughly. $0.2 \%$ cardamom powder was added and balls of Chhana were made. The balls were cooked in sugar syrup (Temperature- $95-100^{\circ} \mathrm{C}$; Brix-52 $2^{\circ}$ ) for $15-20$ minutes. Cooked balls were put in soaking syrup (Temperature- $50-60^{\circ} \mathrm{C}$; Brix $-25^{\circ}$ ) for 8 10 minutes. Prepared rasogolla was packed in plastic cup covered with aluminum foil and stored in refrigerator $\left(7^{\circ} \mathrm{C}\right)$.

\section{Materials and Methods}

The rheological properties of potato powder based rasogolla samples were analyzed using a texture analyzer model number TAHDI (manufactured by stable micro system, U.K.) fitted with a $250 \mathrm{~kg}$ load cell was used under two bites linear compression (Sanyal et al., 2011).

Rasogolla incorporated with potato powder (Chandramukhi and Jyoti) along with control and market samples were coded with different numbers and submitted to sensory evaluation by ten member trained panellists of the department on a 9-point hedonic scale (BIS, 1971).

The data were statistically analyzed using statistical tool ANOVA described by Snedecor and Cochran (1967).

\section{Results and Discussion}

\section{Comparison of sensory quality between laboratory made and market rasogolla}

The overall acceptability score of the entire laboratory made rasogolla and market rasogolla samples were compared and study revealed that the market rasogolla sample (8.2) as well as rasogolla (jyoti) (7.86) and control sample (7.86) were liked moderately by the judges, whereas rasogolla (chandramukhi) were liked very much by the judges (8.71). By using 9 point hedonic scale it was clearly observed that kufri chandramukhi variety potato powder fortified rasogolla got the highest point among all the laboratory made rasogolla and it preceded market sample which is depicted in table 1 and figure 1 .

\section{Comparison of rheological quality between laboratory made and market rasogolla}

The texture profile obtained in this study has been depicted in table 2 and figure 2. From table 2, it has been found that the hardness and springiness of market sample were higher than potato powder based rasogolla samples and lower value were observed in case of fracturability, adhesiveness, cohesiveness, gumminess and chewiness. Rasogolla (Chandramukhi) showed the highest value of cohesiveness and rasogolla (jyoti) showed the highest value of chewiness among all laboratory and market samples.

The laboratory made and market rasogolla samples had significant influence $(\mathrm{p}<0.05)$ on body and texture parameters (Table 1). There was no significant difference $(p>0.05)$ was observed regarding all the other parameters among the varieties of samples. Addition of potato powder as binder may influence the body and textural property of rasogolla. These findings were comparable with the study of Kulkarni et al., 1996. 
Table.1 Sensory quality of different types of rasogolla

\begin{tabular}{|l|c|c|c|c|c|}
\hline Parameters & $\begin{array}{c}\mathbf{C} \\
\text { (avg } \pm \text { sd) }\end{array}$ & $\begin{array}{c}\text { R1 } \\
\text { (avg } \pm \mathbf{s d )}\end{array}$ & $\begin{array}{c}\text { R2 } \\
\text { (avg } \pm \mathbf{s d )}\end{array}$ & $\begin{array}{c}\text { M } \\
\text { (avg } \pm \text { sd) }\end{array}$ & $\begin{array}{c}\text { Level of } \\
\text { Significance }\end{array}$ \\
\hline Taste & $8.14 \pm 0.24$ & $7.43 \pm 0.19$ & $8 \pm 0$ & $8.5 \pm 0.12$ & NS \\
\hline Color & $7.71 \pm 0.17$ & $7.71 \pm 0.17$ & $8 \pm 0$ & $7.1 \pm 0.07$ & NS \\
\hline Flavor & $7.57 \pm 0.20$ & $7.86 \pm 0.13$ & $8 \pm 0$ & $7.8 \pm 0.18$ & NS \\
\hline $\begin{array}{l}\text { Body and } \\
\text { texture }\end{array}$ & $7.57 \pm 0.20$ & $7.14 \pm 0.24$ & $8.43 \pm 0.19$ & $8 \pm 0.26$ & $*$ \\
\hline Sweetness & $7.71 \pm 0.17$ & $7.57 \pm 0.25$ & $8 \pm 0$ & $8.3 \pm 0.13$ & NS \\
\hline $\begin{array}{l}\text { Overall } \\
\text { acceptance }\end{array}$ & $7.86 \pm 0.13$ & $7.86 \pm 0.24$ & $8.71 \pm 0.17$ & $8.2 \pm 0.17$ & NS \\
\hline
\end{tabular}

$\mathrm{C}=$ Control, $\mathrm{R} 1=$ rasogolla (jyoti), $\mathrm{R} 2=$ rasogolla (chandramukhi), $\mathrm{M}=$ rasogolla (market).

$(\operatorname{avg} \pm \mathrm{sd})=$ Average \pm standard deviation; $\mathrm{n}=10$

* Significant at $\mathrm{p}<0.05, \mathrm{NS}=$ Non Significant

Table.2 Rheological quality of different types of rasogolla

\begin{tabular}{|l|c|c|c|c|c|}
\hline \multicolumn{1}{|c|}{ Parameters } & $\begin{array}{c}\mathbf{C} \\
\text { (avg } \pm \text { sd) }\end{array}$ & $\begin{array}{c}\text { R1 } \\
\text { (avg } \pm \text { sd) }\end{array}$ & $\begin{array}{c}\text { R2 } \\
\text { (avg } \pm \text { sd) }\end{array}$ & $\begin{array}{c}\text { M } \\
\text { (avg } \pm \text { sd) }\end{array}$ & $\begin{array}{c}\text { Level of } \\
\text { Significance }\end{array}$ \\
\hline Hardness(g) & $883.3 \pm 374.4$ & $125.7 \pm 75.8$ & $674.7 \pm 278.3$ & $776.7 \pm 9.86$ & $* *$ \\
\hline Fracturability(g) & $36.5 \pm 0.84$ & $35.8 \pm 0.26$ & $36.4 \pm 0.05$ & $35.13 \pm 0.03$ & $*$ \\
\hline Adhesiveness(gs) & $-1.2 \pm 0.84$ & $-0.94 \pm 0.5$ & $-0.36 \pm 0.05$ & $-10.35 \pm 8.18$ & $* *$ \\
\hline Springiness(mm) & $0.7 \pm 0.084$ & $0.55 \pm 0.001$ & $0.72 \pm 0.007$ & $0.758 \pm 0.17$ & $* *$ \\
\hline Cohesiveness & $0.7 \pm 0.085$ & $0.55 \pm 0.001$ & $0.72 \pm 0.007$ & $0.657 \pm 0.024$ & $*$ \\
\hline Gumminess(g) & $980.07 \pm 118.5$ & $695.9 \pm 54.8$ & $822.12 \pm 80.5$ & $518.9 \pm 12.9$ & $* *$ \\
\hline Chewiness(gmm) & $228.8 \pm 830.08$ & $663.9 \pm 60.1$ & $235.5 \pm 385.6$ & $350.7 \pm 75.15$ & $* *$ \\
\hline
\end{tabular}

$\mathrm{C}=$ Control, $\mathrm{R} 1=$ rasogolla (jyoti), $\mathrm{R} 2=$ rasogolla (chandramukhi), $\mathrm{M}=$ rasogolla (market).

$(\operatorname{avg} \pm \mathrm{sd})=$ Average \pm standard deviation; $\mathrm{n}=4$

* Significant at $\mathrm{p}<0.05, * *$ Significant at $\mathrm{p}<0.01$

Fig.1 Sensory analysis of different types of rasogolla

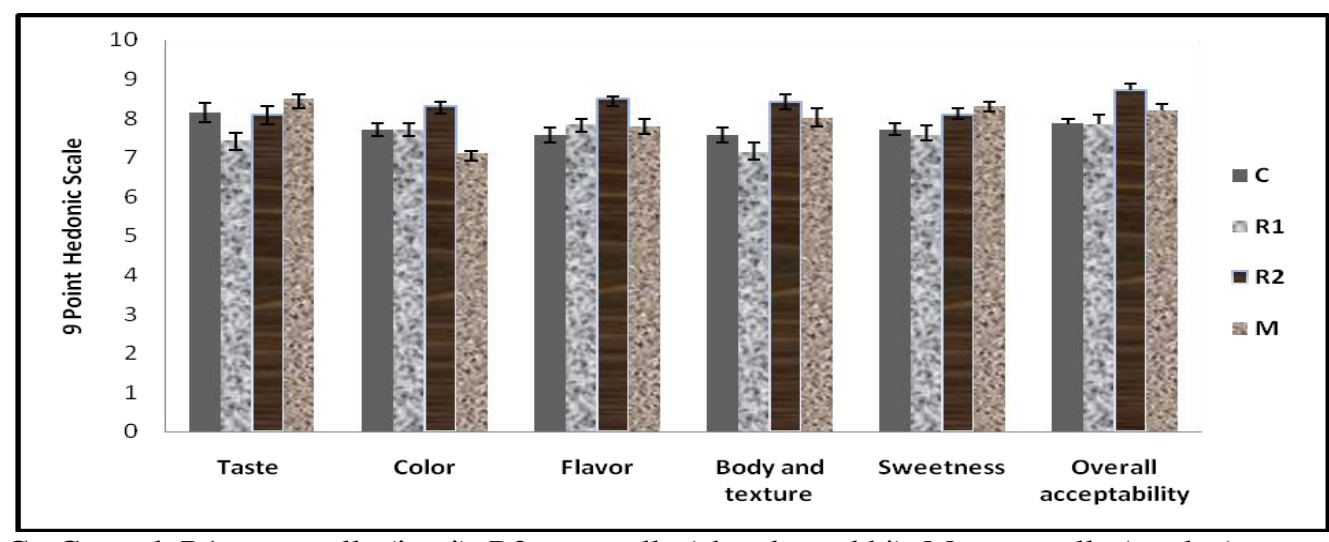

$\mathrm{C}=\mathrm{Control}, \mathrm{R} 1=$ rasogolla (jyoti), $\mathrm{R} 2=$ rasogolla (chandramukhi), $\mathrm{M}=$ rasogolla (market) 
Fig.2 Textural analysis of different types of rasogolla

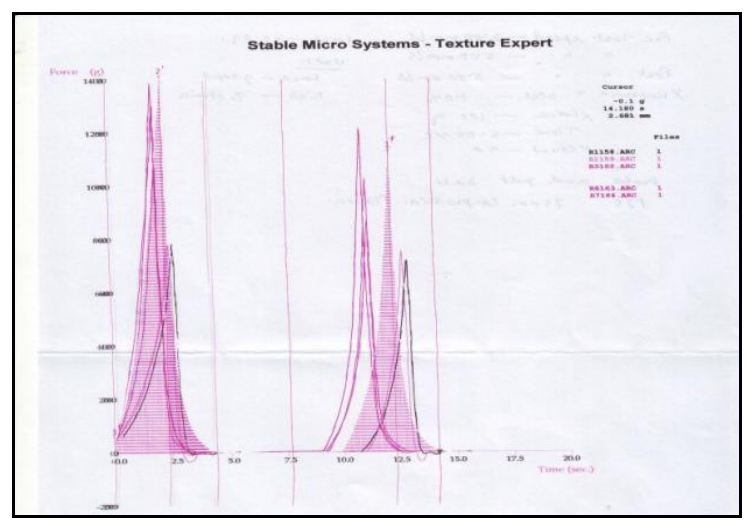

The unique feature of Indian traditional dairy products is that they are obtained by a wide variety of methods involving a range of unit operations. This leads to a great range of product structures and textures. The chemical components of traditional dairy products including incorporation of food additives, and the specific processing conditions would determine the texture and microstructure of the products (Prasad, 1998). Retaining the product's complex texture, while adopting modified or new processes, is a real challenge to the manufacturer. Hence, characterization of a product's texture is valuable not only in process development but also in monitoring the textural quality in routine production. Instrumental textural data have been correlated with sensory data for several traditional dairy products (Patel et al., 2005).

Table 2 showed that laboratory made as well as market samples had significant influence on hardness $\quad(p<0.01)$, gumminess $\quad(p<0.01)$, chewiness $(p<0.01)$, adhesiveness $(p<0.01)$, cohesiveness $(\mathrm{p}<0.05)$, fractuability $(\mathrm{p}<0.05)$ and springiness $(\mathrm{p}<0.01)$. Patel et al., (1990) reported that increase in total solids considerably increase hardness, gumminess and chewiness but decrease cohesiveness. Bandyopadhyay et al., (2007) reported that addiution of additives (carrot) gave more porous structure and reduced firmness in rasogolla and also reduced fat content increase stickiness. Sweet potato flour addition reduced the springiness, cohesiveness, and resilience of the cooked noodles, but exerted varied effects on hardness and adhesiveness (Zhang et al., 2010). Moisture and fat had a negative and positive effect respectively $(P<0.01)$ on adhesiveness of sandesh. Chewiness was negatively and positively inûuenced $(\mathrm{P}<0.01)$ by the moisture and fat content of sandesh, respectively (Khamrui and Solanki, 2010). Incorporation of carrageenan at $0.1 \%$ level produced better result in terms of textural and sensory profile of sandesh as compared to $0,0.075$ and $0.125 \%$ levels (Sanyal et al., 2011).

It can be concluded that laboratory made rasogolla can be prepared by using $3 \%$ of kufri chandramukhi variety potato powder with highest consumer acceptability as compared to the other type of samples. It is seen that the main advantage of using potato powder in the preparation of rasogolla is that it provides a low-fat value added product with increased deliciousness and nutritional characteristics. Hence, it is possible to meet both national and international export demand for potato powder fortified Indian milk dessert rasogolla.

\section{Acknowledgement}

The authors are hereby acknowledging the Honorable Managing Director of JIS Group for financial support and inspiration. Authors are very much grateful to the Department of Dairy Technology, Faculty of Dairy Technology, WBUAFS, Mohanpur campus for providing the laboratory facilities in carry out the textural analysis of potato powder fortified rasogolla. 


\section{References}

Avula, R.Y., Guha, M., Tharanathan, R.N. and Ramteke, R.S. (2006). Influence of drying conditions on functional properties of potato flour, European Food research Technology, 223:553560.

Bandyopadhyay M., Chakraborty R. and Raychaudhuri, U. (2007). Role of carrot on shelf stability of dairy dessert (rasogolla) during refrigerated storage, Journal of Food Processing and Preservation, 31 (6): 714-735.

Bandyopadhyay, M., Chakraborty, R. and Raychaudhuri, U. (2007). Physical and sensory characteristics of low fat dairy dessert (Rasogolla) fortified with natural source of $\beta$-carotene, Journal of Scientific and Industrial Research, 66:757-763.

Bastos-Cardoso, I., Zazueta-Morales, J.D.J., Matinez-Bustos, F. and Kil-Chang, Y. (2007). Development and characterization of extruded pellets expanded by microwave heating, Cereal Chemistry, 84: 137-144.

Bhattacharya DC, Mathur PM, Srinivasan MR and Samlik O, 1971. Studies on the method of production and self life of paneer, J. of Food Sci Technol, 7: 117119

BIS (1971) IS: 6273. Guide for sensory evaluation of foods. Part two. Methods and evaluation cards. Bureau of Indian Standards. Manak bhavan, New Delhi.

Chakraborty, C., Banyopadhyay K. and Barman, A.K. (2012). Nutritional and Rheological Characterization of Potato Powder Based Indian Traditional Dairy Product: Kheer, Wesleyan Journal of Research, 5(1): 42-49, 2012. ISSN: 0975-1386.

Chavan, R.S., Prajapati, P.S., Chavan, S.R. and Khedkar, C.D. (2009). Study of manufacture and shelf-life of Indian Dietetic and Diabetic Rosogolla, International Journal of Dairy Science, 4(4): 129-141.
De S and Ray SC, 1954. Studies on the indigenous method of chhana making. Indian J Dairy Sci, 7: 113.

Gahlawat P. and Sehgal, S. (1996). Protein and starch digestibilities and mineral availability of products developed from potato, soy and gram flour, Plant Foods for Human Nutrition, 52: 151-160.

International Year of the Potato 2008 - The potato". United Nations Food and Agricultural Organisation. 2009. Retrieved 26 October 2011.

Karunanithy, C., Varadharaju N. and Kailappan, R.(2007). Studies on the development of the kneader and ball former for chhana in Rasogolla production: Part III. Quality parameters of Rasogolla, $J$. Food Engg., 80: 966-971.

Khamrui, K and Solanki, D.C. (2010) The relationship of textural characteristics with composition of sandesh produced from various market milk classes. International Journal of Dairy Technology. 63: 451-456.

Kulkarni K.D., Govinden N., Kulkarni D. (1996) Production and use of raw potato flour in Mauritian traditional foods. Food and Nutrition Bulletin, 17(2). The United Nations University Press.

Marwaha, R.S. and Sandhu, S.K. (1996). Annual Scientific Report. Central Potato Research Station, 1996, Indian Council of Agricultural Research, Jalandhar, India, Pp 6.

Mishra, A. and Kulshrestha, K. (2002). Effect of storage on microbial safety of potato flour, Journal of Food Science and Technology, 39: 517-519.

Nath, A. and Chattopadhyaya, P.K. (2008). Effect of process parameters and soy flour concentration on quality attributes and microstructural changes in ready-toeat potato-soy snack using high temperature short time air puffing, Lebensmittel Wissenschaft und Technologie, 41:707-715.

Patel, J.S., Bhadania, A.G and Boghra, V.R (2005). Chemical composition and 
sensory evaluation of sandesh manufactured in scraped surface heat exchanger (SSHE). J. Dairying, Foods and Home Sci, 25: 28-33

Patel AA, Patil GR, Grag FC and Rajorhia GS, 1990. Texture of peda as measured by Instron. XXIII Intern. Dairy Cong, 2: 627

Prasad, D. N. (1998). Microstructure of traditional dairy products. In: Lecture compendium on "Advances in Traditional Dairy Products", Fourth Short Course, Centre of Advanced Studies, NDRI, Karnal. Pp: 134-139.

Raj, D., Lal, B.B., Sharma, P.C. and Vaidya, D. (2008). Development of ready-to-use instant custard powder from un marketable potatoes. Journal of Food Science and Technology, 45: 361-363.

Rekha, M.N., Avula, R.Y., Dharmesh, S.M., Chauhan, A.S. and Remteke, R.S. (2009). Evaluation of antioxidant properties of dry soup mix extracts containing Dill (Anethum sowa L) leaf, Food and Bioprocess Technology, in press.

Saha, J., Chakraborty, C. and Banyopadhyay K. (2014). Development of Healthy Appetizer Using Sweet Potato Powder as Functional Ingredient, Beverage and Food World, 41(4): 48-49. ISSN: 09706194.

Sanyal M.K., Pal S.C., Gangopadhyay S.K., Dutta S.K., Ganguli D., Das S. and Maiti P., (2011) Influence of stabilizers on quality of sandesh from buffalo milk. J Food Sci Tecnol, 48(6):740-744.

Snedecor G.W., Cochran W.G., Statistical Methods. Oxford and IBH Publ Co, Calcutta, India, 1967.

Zhang,W., Sun,C., He,F. and Tian, J.(2010). Textural Characteristics and Sensory Evaluation of Cooked Dry Chinese Noodles Based on Wheat-Sweet Potato Composite Flour, International Journal of Food Properties, 13(2):294-307.

\section{How to cite this article:}

Chaitali Chakraborty and Kakali Bandyopadhyay. 2017. Textural Analysis of Spongy Indian Milk Dessert (Rasogolla) Fortified with Potato Powder. Int.J.Curr.Microbiol.App.Sci. 6(4): 2414-2420. doi: https://doi.org/10.20546/ijcmas.2017.604.281 